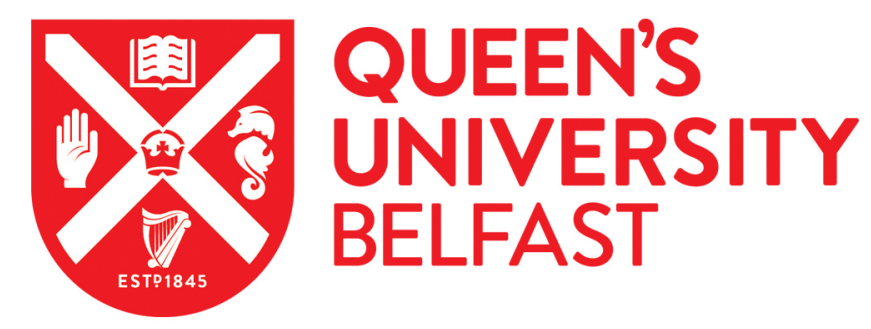

\title{
Effectiveness of copper ions against Mycobacterium avium subsp. paratuberculosis and bacterial communities in naturally contaminated raw cow's milk
}

Steuer, P., Tejeda, C., Martinez, O., Ramirez-Reveco, A., González, N., Grant, I. R., Foddai, A., Collins, M. T., \& Salgado, M. (2021). Effectiveness of copper ions against Mycobacterium avium subsp. paratuberculosis and bacterial communities in naturally contaminated raw cow's milk. Journal of Applied Microbiology, 131(1), 146154. https://doi.org/10.1111/jam.14923

Published in:

Journal of Applied Microbiology

Document Version:

Peer reviewed version

Queen's University Belfast - Research Portal:

Link to publication record in Queen's University Belfast Research Portal

Publisher rights

(c) 2020 The Society for Applied Microbiology

This work is made available online in accordance with the publisher's policies. Please refer to any applicable terms of use of the publisher.

\section{General rights}

Copyright for the publications made accessible via the Queen's University Belfast Research Portal is retained by the author(s) and / or other copyright owners and it is a condition of accessing these publications that users recognise and abide by the legal requirements associated with these rights.

\section{Take down policy}

The Research Portal is Queen's institutional repository that provides access to Queen's research output. Every effort has been made to ensure that content in the Research Portal does not infringe any person's rights, or applicable UK laws. If you discover content in the

Research Portal that you believe breaches copyright or violates any law, please contact openaccess@qub.ac.uk. 
1 Effectiveness of copper ions against Mycobacterium avium subsp. paratuberculosis and

2 bacterial communities in naturally contaminated raw cow's milk

3

4 P. Steuer ${ }^{1,3}$, C. Tejeda ${ }^{1}$, O. Martinez ${ }^{4}$, A. Ramirez-Reveco ${ }^{2}$, N. González ${ }^{1}$, I.R. Grant ${ }^{5}$, A.C.G.

$5 \quad$ Foddai $^{5}$, M.T. Collins ${ }^{6}$, M. Salgado ${ }^{1 *}$

6

$7 \quad{ }^{1}$ Instituto de Medicina Preventiva Veterinaria, ${ }^{2}$ Instituto de Ciencia Animal, ${ }^{3}$ Escuela de

8 Graduados, Facultad de Ciencias Veterinarias, and ${ }^{4}$ Instituto de Bioquímica y Microbiología,

9 Universidad Austral de Chile, Valdivia, Chile; ${ }^{5}$ Institute for Global Food Security, School of

10 Biological Sciences, Queen's University Belfast, Belfast, Northern Ireland, United Kingdom,

$11{ }^{6}$ Department of Pathobiological Sciences, School of Veterinary Medicine, University of

12 Wisconsin, Madison, USA.

13

14 Running headline: Copper to control MAP in milk

* Corresponding author: Miguel Salgado. Instituto de Medicina Preventiva Veterinaria -

Facultad de Ciencias Veterinarias, Universidad Austral de Chile. Saelzer Building $5^{\circ}$ Floor,

Campus Isla Teja, PO Box 567, Valdivia, Chile. Phone: +56 63-2 444358. Fax: +56 63-293- 


\section{Abstract}

\section{Aim}

The focus of the present study was the evaluation of the copper ions treatment on the viability of Mycobacterium avium subsp. paratuberculosis (MAP) and other bacterial communities in cow's milk.

\section{Methods and Results}

A copper ions treatment was evaluated in naturally contaminated cow's milk to assay MAP load and/or viability; and relative abundance of other bacterial communities. In addition, physical-chemical analysis of the milk was also performed. All analyses were carried out before and after a copper ions treatment. After copper ions treatment, $\mathrm{pH}$ and copper concentration markedly increased in milk; the numbers of viable MAP significantly decreased. The relative abundance of the four target phyla decreased, with the phyla Bacteroidetes and Firmicutes surviving treatment in higher proportions (4\% and $2.1 \%$, respectively). A progressively higher percentage of dead bacterial cells after 5 min and 20 min copper ions treatments was found ( $12 \%$ and $35 \%$, respectively).

\section{Conclusion}

With the exception of some MAP tolerant strains, we have once again demonstrated that copper ions have a signifcant inactivating effect on MAP as well as certain other bacterial communities found in naturally contaminated cow's milk.

\section{Significance and Impact of Study}

This study showed a significant inactivation of both MAP and other bacteria by copper ions in raw cow's milk, information that could be useful as a tool for MAP control.

Keywords: milk, paratuberculosis, MAP, copper, treatment, bacterial communities 
52 Raw cow's milk contains a diverse microbial population and is an ideal environment for the growth of many microorganisms (Quigley et al. 2013). Microorganisms may enter milk from a variety of sources such as teat canal, surface of teat skin, feces, housing, bedding, feed, air, environmental conditions. 
Recommendations to control paratuberculosis in dairy herds, such as surveillance and biosecurity measures, have been rather inefficient and thus new control approaches against this pathogen are necessary (Bastida and Juste 2011). Prior studies showed that MAP commonly contaminates raw milk, even when the milk originates from cows that are testnegative for paratuberculosis (Steuer et al. 2019).. Pasteurization has been used to reduce the MAP load in colostrum and milk. However, MAP is heat-resistant and multiple studies show that although several logs of MAP are killed, many MAP cells survive pasteurization (Grant et al. 1996; Grant et al. 2002; Hammer et al. 2002; Grant et al. 2005). MAP also has been recovered from powdered infant formula (Botsaris et al. 2016) and calf milk replacer (Grant et al. 2017), both of which are pasteurized products. Thus, there is a need for methods to inactivate MAP in raw milk.

The use of copper as an antimicrobial was officially approved for use in 2008 by the United States Environmental Protection Agency (EPA 2008). We previously showed that copper ions can cause a significant reduction of viable MAP in a liquid matrix (phosphate buffered saline, PBS), although some MAP strains tolerated copper ions (Steuer et al. 2018). Our study aim was to evaluate the effect of copper ions on the viability of MAP and other bacterial communities in naturally contaminated cow's milk.

\section{Materials and methods}

\section{Study design}

The milk was obtained from a dairy herd (Los Ríos Region, Chile) with a history of clinical cases of paratuberculosis and cows that had positive fecal culture results (54\% of the adult herd).

The in vitro experiments were performed to evaluate the effect of copper ions on the viability of MAP and bacterial communities' survival in eight independent naturally contaminated 
101 milk samples. A 11 sub-sample of naturally contaminated milk intended for calf feeding was collected. From each milk sample, $1 \mathrm{ml}$ was processed for cDNA extraction, in order to to confirme IS900 target MAP gene presence, on the day of collection; the rest of it was frozen at $-80^{\circ} \mathrm{C}$ for up to 2 weeks prior to the PMS-phage assay $(50 \mathrm{ml}$ from the original sample).

105 Experiments were performed in duplicate.

\section{Copper ions treatment of raw milk and ancillary study data}

108 The copper treatment device consisted of a 0.51 beaker glass in which two high purity copper

109 plates were immersed. The setup of the copper treatment apparatus was the same as reported

110 previously (Steuer et al. 2018). The copper plates were stimulated with a low voltage (24V)

111 electrical current (3 Amperes) for 5 min to quickly release copper ions (i.e. complete

112 treatment). For one experiment, the treatment time was extended to $20 \mathrm{~min}$. The milk was

113 mixed constantly during treatment.

114 In parallel to the main study, a complementary descriptive one, was performed. Firstly, the

115 effect of copper treatment without the use of an electrical current was evaluated. Secondly,

116 MAP was exposed to copper using copper sulphate $\left(\mathrm{CuSO}_{4}\right)$, at different concentrations $(6.5$

$117 \mu \mathrm{M}-100 \mathrm{mM})$. In addition, $\mathrm{pH}$, conductivity, dissolved oxygen and copper concentrations

118 were evaluated before and after the application of copper ions treatment: $\mathrm{pH}$ was measured by

119 an electrode (Orion, model 420A); conductivity by an electrode (Hanna Instrumental,

120 edge $\left.{ }^{\mathrm{TM}}\right)$; dissolved oxygen consumption by oximeter (Oxy 730, Inolab); and copper

121 concentration by the atomic absorption spectrophotometry (GBC scientific equipment,

122 SavantAA). Each determination was performed before and after treatment within the first 5

$123 \mathrm{~min}$, in triplicate, and the results were expressed as mean values. 
Peptide mediated magnetic separation (PMS)-Phage amplification assay. This assay

128

129

130

allowed us to quantitatively determine MAP viability in treated and non-treated milk samples. Fifty $\mathrm{ml}$ of milk was prepared and processed by PMS-Phage assay according to a published protocol (Foddai and Grant 2015). To confirm the identity of Mycobacterium sp. causing plaques, up to 10 plaques were cut from the agar and pooled before DNA was extracted and purified as described by Swift et al. (2013) and finally tested to confirm MAP by real-time IS900 PCR (Salgado et al. 2014).

\section{MAP detection and bacterial load estimation using qPCR. To complement MAP detection} and quantification by the phage assay, a real-time PCR protocol was carried out according to a published protocol (Salgado et al. 2014), before and after copper-treatment. Quantification was based on a standard curve for the estimation of MAP numbers by Roche 2.0 real-time IS900 PCR (Steuer et al. 2018). Real-time PCR-derived copy numbers of the target region were expressed as MAP-specific bacterial cell equivalents (bce), according to Dzieciol et al. (2010).

Detection of viable bacterial communities in raw cow's milk. An RNA isolation, from raw milk, followed by cDNA synthesis was performed, using TRIzol method as recommended by the manufacturer (Invitrogen).

Taxon-specific qPCR protocol. Primers targeting high taxonomic groups such as the phyla Bacteroidetes, Firmicutes, Actinobacteria and the $\gamma$ subdivision of Proteobacteria, were used to amplify the milk-derived cDNA. The primers and qPCR conditions were those described by Bacchetti et al. (2011). 
152 abundance of different bacterial communities present in raw milk samples before and after 153 treatment with copper ions was compared by calculating the efficiency of each primer pair 154 used (Mygind et al. 2002), and by normalizing the quantification to a control gene Bacchetti 155 et al. (2011).

\section{Live/Dead staining}

158 A fluorescent live/dead staining technique was applied to milk samples before and after

159 copper ions treatment for 5 and 20 min to differentiate cells treated with or without copper

160 ions with undamaged and damaged permeable membranes. The samples were stained with

161 Hoechst 33342/Propidium iodide, according to the manufacturer's protocol (Invitrogen). The

162 slides were mounted, and stained cells were visualized (40x magnification) and evaluated

163 using an inverted epifluorescence microscope (Leica DMI3000 B) coupled to a digital camera

164 (Leica DFC 425 C). Images were processed with Adobe Photoshop 6.0. Viability percentages

165 were estimated after examining at least 100 cells in different fields.

\section{Statistical analysis}

168 MAP plaque counts (PFU) and qPCR genome equivalents were measured before and after

169 milk sample treatment. The Wilcoxon matched-pairs signed rank test was used to compare

170 pre- and post-treatment PFU and qPCR results.

171 The Spearman correlation coefficient test was used to assess the relationship between

172 numbers of MAP detected before copper treatment through PMS-phage assay and qPCR, with

173 both counts expressed per ml of milk.

174 In addition, the calculated percentages of $16 \mathrm{~S}$ taxon-specific copy numbers present in raw

175 milk samples before and after treatment were plotted on a bar chart and differences evaluated 
by a paired $t$-test. Differences in bacterial viability by live/dead staining between treatments were evaluated using the ANOVA Kruskal-Wallis test, followed by the multiple comparisons Dunn test. All data analyses were performed using GraphPad Prism 6 software, and for all analyzes, differences with $\mathrm{P}<0.05$ were considered significant.

\section{Results}

182 The application of the copper ions treatment together with an electrical current (complete copper ions treatment) resulted in a decrease, on average, of $2 \log _{10}$ in MAP numbers in comparison to exposure to copper without an electrical current (Table 1). The complete treatment also, increased the copper concentration in milk from 0.61 to $15.0 \mathrm{mg} \mathrm{l}^{-1}$, and the $\mathrm{pH}$ value in the milk sample from 7.5 before treatment to 12 (Table 1); slightly increased the electrical conductivity of the milk; and gradually decreased the oxygen concentration in the same sample (Table 1). No reduction in MAP load was observed after treating MAPcontaminated milk with copper sulphate, even at a concentration of $100 \mathrm{mM}$ (Table 2). Variable numbers of viable MAP (median $1.75 \times 10^{4} \mathrm{PFU}$ per $50 \mathrm{ml}$ ) were detected in raw

192 milk by PMS-phage assay and this decreased significantly after copper ions treatment $(\mathrm{P}=$ 0.0078, mean $1.79 \log _{10}$ reduction, Table 3). MAP numbers were also lower after copper treatment when IS900 qPCR was employed to calculate bacterial cell equivalents (bce) $(\mathrm{P}<$ 0.0063). While IS900 qPCR estimated $3.7 \times 10^{3} \mathrm{MAP}$ bce $\mathrm{ml}^{-1}$ before treatment, for 7 of 8

196 replicates, MAP was not detectable by IS900 qPCR after copper treatment (Table 4).

197 Spearman correlation coefficient test to assess the relationship between MAP numbers estimated by phage assay and qPCR showed a weak correlation $(\rho=-0.38)$. 
The estimated slope of the line and the efficiencies calculated for each pair of primers used in 201 this study (Universal and taxon-specific) are given in Table 5. Using 16S rRNA copy number estimates, the phylum $\gamma$-proteobacteria, followed by the phyla Firmicutes and Bacteroidetes dominated the bacterial communities in raw milk (Figure 1). The relative abundance of all the bacterial communities in raw milk decreased after copper ions treatment (Figure 1). Live/dead staining showed that copper ions treatment applied for $20 \mathrm{~min}$, but not $5 \mathrm{~min}$, significantly reduced $(\mathrm{p}<0.005)$ the proportion viable bacterial cells compared to pretreatment controls (Figure 2).

\section{Discussion}

210 The focus of this research was on decreasing the number of viable MAP in milk fed to calves.

211 Numerous studies have confirmed the antimicrobial properties of copper and copper alloys 212 (Faundez et al. 2004; Wilks et al. 2005; Noyce et al. 2006a, 2006b; Methar et al. 2008; Grass et al. 2011). In a previous study we demonstrated for the first time the ability of copper ions to significantly decrease viable MAP numbers in a liquid matrix (PBS) (Steuer et al. 2018).

The present study included some variables $(\mathrm{pH}$, conductivity, dissolved oxygen and copper concentrations) that were not considered previously (Steuer et al. 2018). The ancillary study data indicated that stimulation of the copper plates with an electrical current causes a faster and larger release of copper ions from the plates compared to no application of electric current. The latter is consistent with the high concentration of copper measured in milk after treatment (20 times more than without electrical current application). Some studies suggest that electrical current alone does not have a bactericidal effect; however, bacteria in biofilms can synergistically be controlled when applying an electrical current together with biocides or antimicrobial agents (Costerton et al. 1994; Jass et al. 1996; Versoza et al. 2019). Electrical 
current may be less effective in milk since we observed that the amperage gradually decreased.

The minimal inhibitory concentration (MIC) of copper sulphate for S. aureus, Salmonella and E. coli ranged from $2-12 \mathrm{mM}, 20-28 \mathrm{mM}$ and 16-20 mM, respectively (Aarestrup and Hasman 2004). Interestingly, we did not observe any reduction in MAP viability using copper 231 sulphate at concentrations up to $100 \mathrm{mM}$.

233 Copper can act as an electron donor/acceptor by alternating between the redox states $\mathrm{Cu}^{+1}$ and

$234 \mathrm{Cu}^{+2}$ (Karlin 1993). Therefore, the higher concentration of copper ions released, when treating 235 milk with copper plates stimulated with an electrical current, may have reacted with the 236 oxygen, decreasing its free concentration in milk. On the other hand, the redox properties of copper can also cause cellular damage (Grass et al. 2011). In addittion, the antimicrobial

238 effects observed may have been due to the high alkalinity reached ( $\mathrm{pH} 11.7)$ after $5 \mathrm{~min}$ 239 treatment which could denature microbial structural proteins (De Benedictis et al. 2007) or 240 saponify their cell wall (Katayama et al. 2001).

242 Although it is unclear the mechanism of action of the copper ions, significant inactivation of 243 MAP $(p=0.0063)$ and the decreasing of other bacteria by the complete copper ions treatment 244 was observed. The PMS-phage method (Foddai et al. 2010) revealed roughly a $2 \log _{10}$ 245 reduction in viable MAP counts after copper ions treatment ( $24 \mathrm{~V}$ x $5 \mathrm{~min}$ ). This reduction is 246 lower than that the 3 to $6 \log _{10}$ MAP cells reported for pasteurization (Stabel et al. 2004; 247 McDonald et al. 2005; Grant et al. 2005; Rademaker et al. 2007; Hammer et al. 2014). 
Staining of bacterial cells with Hoechst 33342/Propidium iodide (live-dead) stain confirmed

250 that copper ions cause a loss in the bacterial cell viability in milk, but this was only significant

251 after a 20 min treatment (Figure 2).

252 MAP counts before copper ions treatment estimated by IS900 qPCR and PMS-phage assay 253 were weakly correlated $(\rho=-0.38)$, where a slightly higher number of MAP per ml was 254 reported by IS900 qPCR. The lower PFU counts per ml may be explained by counting of 255 clumps of cells rather than just single cells, although milk samples were declumped by 256 ultrasonication, maybe different degrees of declumping were achieved (Foddai and Grant 2017). The higher estimation of MAP per ml by IS 900 qPCR could be because this technique would not have discriminated between viable cells and nonviable MAP cells. However, after copper ions treatment MAP was not detected. These results strongly suggest that copper ions cause direct DNA damage in MAP cells, as has been reported elsewhere for other bacteria (Warnes et al. 2010).

The phylum $\gamma$-proteocbacteria, followed by the phyla Firmicutes and Bacteroidetes, were the

264 dominant bacterial communities detected in raw cow's milk employed in this study.

265 Firmicutes and Bacteroidetes bacteria best tolerated copper ions treatment which suggests that copper ions may not be as effective in killing bacterial communities that resist adverse environmental conditions by sporulation. Those copper tolerant MAP strains may use a similar survival strategy since it can produce spore-like structures (Lamont et al. 2012), as do many members of the Firmicutes group (Filippidou et al. 2015).

271 MAP and the most copper tolerant bacterial communities may use one or more heavy metal 272 resistance mechanisms that have been described for bacteria in general. These mechanisms 273 include exclusion by permeability barriers, intra- and extra-cellular sequestration, active 
274 transport membrane efflux pumps, enzymatic detoxification, and reduction in the sensitivity

275 of cellular targets to metal ions (Borkow and Gabbay 2005). Alternatively, this apparent MAP

276 tolerance to copper treatment could simply be a function of its thick, lipid-rich and relatively

277 impermeable cell wall (Whan et al. 2001; Grant et al. 2002). Also, MAP in raw milk is

278 primarily located inside somatic cells which provides additional protection (Gerrard et al.

279 2018).

280

281 Although some MAP and bacterial communities strains were observed to survive copper ions

282 treatment, we have again demonstrated that copper ions had an significant inactivating effect

283 on MAP, as well as other bacterial communities, occurring in milk. Whether such a treatment

284 represents an effective and practical decontamination method for inactivating MAP in milk

285 being fed to calves on farms requires further study.

286

287 Acknowledgements: This work was supported by FONDECYT Grant (1161633). Pamela

288 Steuer was the recipient of a Doctoral Studentship from the Chilean government (CONICYT)

289 during the present study and it was part of a Doctoral Thesis of the Universidad Austral de

290 Chile.

291

292 Conflict of interest: The authors declare no conflict of interest

293

294

295 


\section{References}

Aarestrup, F. M. and Hasman, H. (2004) Susceptibility of different bacterial species isolated

299 from food animals to copper sulphate, zinc chloride and antimicrobial substances used for

300 disinfection. Vet Microbiol 100, 83-89.

301

302 Bacchetti, T., Aldred, N., Clare, A. and Grant, J. (2011) Improvement of phylum- and class-

303 specific primers for real-time PCR quantification of bacterial taxa. J Microbiol Methods 86, $304 \quad 351-356$.

305

306 Bastida, F.and Juste, R. (2011) Paratuberculosis control: a review with a focus on vaccination.

307 J Immune Based Ther Vaccines 9, 1-17.

308

309 Borkow, G. and Gabbay, J. (2005) Copper as a Biocidal Tool. Curr Med Chem 12, 2163-

3102175.

311

312 Botsaris, G., Swift, B., Slana, I, Liapi, M., Christodoulou, M., Hatzitofi, M., Christodoulou,

313 V. and Rees, C. (2016) Detection of viable Mycobacterium avium subspecies

314 paratuberculosis in powdered infant formula by phage-PCR and confirmed by culture. Int $J$

315 Food Microbiol 216, 91-94.

316

317 Costerton, J. W., Ellis, B., Lam, K., Johnson, F. and Khoury, A. E. (1994) Mechanism of

318 electrical enhancement of efficacy of antibiotics in killing biofilm bacteria. Antimicrob Agents

319 Chemother 38, 2803-2809.

320 
De Benedictis, P., Beato, M. and Capua, I. (2007) Inactivation of avian influenza viruses by

322 chemical agents and physical conditions: a review. Zoonoses Public Hlth 54, 51-68.

Dzieciol, M., Volgger, P., Khol, J., Baumgartner, W., Wagner, M. and Hein, I. (2010) A novel real-time PCR assay for specific detection and quantification of Mycobacterium avium subsp. paratuberculosis in milk with the inherent possibility of differentiation between viable and dead cells. BMC Res Notes 3:251.

Environmental Protection Agency (2008) http://gochemless.com/pdf/EPA_

Faúndez, G., Troncoso, M., Navarrete, P. and Figueroa, G. (2004) Antimicrobial activity of copper surfaces against suspensions of Salmonella enterica and Campylobacter jejuni. BMC Microbiol 4:19.

Fecteau, M-E. (2018) Paratuberculosis in cattle. Vet Clin Food Anim 34, 209-222. Biotechnol J 13, 299-306.

342 Foddai, A., Elliott, C. T. and Grant, I. R. (2010) Maximizing capture efficiency and specificity of magnetic separation for Mycobacterium avium subsp. paratuberculosis cells. Appl Environ Microbiol 76, 7550-7558. 
346 Foddai, A. and Grant, I. R. (2015) An optimized milk testing protocol to ensure accurate

347 enumeration of viable Mycobacterium avium subsp. paratuberculosis by the PMS-phage

348 assay. Int Dairy J 51, 16-23.

350 Foddai, A.C.G. and Grant I.R. (2017) Sensitive and specific detection of viable

351 Mycobacterium avium subsp. paratuberculosis in raw milk by the peptide-mediated magnetic

352 separation-phage assay. J Appl Microbiol 122, 1357-1367.

354 Gerrard, Z., Swift, B., Botsaris, G., Davidson, R., Hutchings, M., Huxley, J. and Rees, C.

355 (2018) Survival of Mycobacterium avium subspecies paratuberculosis in retail pasteurized 356 milk. Food Microbiol 74, 57-63.

Grant, I. R., Ball, H. J., Neill, S.D. and Rowe, M.T. (1996) Inactivation of Mycobacterium paratuberculosis in cows' milk at pasteurization temperatures. Appl Environ Microbiol 62, $2631-2636$.

Grant, I. R, Hitchings, E. I, McCartney, A., Ferguson, F. and Rowe, M. T. (2002) Effect of commercial-scale high-temperature, short-time pasteurization on the viability of Mycobacterium paratuberculosis in naturally infected cows' milk. Appl Environ Microbiol 68, 602-7. pasteurization time-temperature conditions in combination with homogenization on

369 inactivation of Mycobacterium avium subsp. paratuberculosis in milk. Appl Environ Microbiol 71, 2853-2861. 
371 Grant, I.R., Foddai, A., Tarrant, J., Kunkel, B., Hartmann, F.A., McGuirk, S., Hansen, C.,

372 Talaat, A.M. and Collins, M.T. (2017) Viable Mycobacterium avium ssp. paratuberculosis

373 isolated from calf milk replacer. J Dairy Sci, 100, 1-13.

374

375 Grass, G., Rensing, C. and Solioz, M. (2011) Metallic copper as an antimicrobial surface.

376 Appl Environ Microbiol 77, 1541-7.

377

378 Hammer, P., Kiesner, C., Walte, H. G., Knappstein, K. and Teufel, P. (2002) Heat resistance

379 of Mycobacterium avium ssp. paratuberculosis in raw milk tested in a pilot plant pasteurizer.

$380 \quad$ Kieler Milchw Forsch 54, 275-303.

381

382 Hammer, P., Kiesner, C. and Walte, H. (2014) Short communication: Effect of

383 homogenization on heat inactivation of Mycobacterium avium subspecies paratuberculosis in

384 milk. J Dairy Sci 97, 2045-2048.

385

386 Harris, N. B. and Barletta, R.G. (2001) Mycobacterium avium subsp. paratuberculosis in

387 Veterinary Medicine. Clin Microbiol Rev 14, 489-512.

388

389 Jass, J., and Lappin-Scott, H. M. (1996) The efficacy of antibiotics enhanced by electrical

390 currents against Pseudomonas aeruginosa biofilms. J Antimicrob Chemother 38, 987-1000.

391

392 Karlin, K. D. (1993). Metalloenzymes, structural motifs, and inorganic models. Science 261, $393 \quad 701-708$. 
Katayama, K., Matsui, R., Hatanaka, T. and Koizumi, T. (2001) Effect of pH on skin

396 permeation enhancement of acidic drugs by 1-menthol-ethanol system. Int J Pharm 226, 6939780.

398

399 Lamont, E. A., Bannantine, J. P., Armién, A., Ariyakumar, D. S. and Sreevatsan, S. (2012)

400 Identification and Characterization of a Spore-Like Morphotype in Chronically Starved 401 Mycobacterium avium subsp. paratuberculosis Cultures. PLoS ONE 7, 1-10.

402

403 Lombard, J.E. (2011). Epidemiology and Economics of Paratuberculosis,

404 Vet Clin N Am-Food A, 27, 525-535.

405

406 Mehtar, S., Wiid, I. and Todorov, S. D. (2008) The antimicrobial activity of copper and 407 copper alloys against nosocomial pathogens and Mycobacterium tuberculosis isolated from 408 healthcare facilities in the Western cape: an in-vitro study. J Hosp Infect 68, 45-51.

409

410 McDonald, W., O’Riley, K., Schroen, C. and Condron, R. (2005) Inactivation of

411 Mycobacterium avium subsp. paratuberculosis in Milk. Appl Environ Microbiol 71, 17854121789.

413

414 Mygind, T., Birkelund, S., Birkebaek, N., Østergaard, L., Skov, J. and Cheistiansen, G.

415 (2002) Determination of PCR efficiency in chelex-100 purified clinical samples and 416 comparison of real-time quantitative PCR and conventional PCR for detection of Chlamydia 417 pneumoniae. BMC Microbiol 2:17.

418 
419 Noyce, J. O., Michels, H. and Keevi, C. W. (2006a) Potential use of copper surfaces to

420 reduce survival of epidemic methicillin resistant Staphylococcus aureus in the healthcare

421 environment. J Hosp Infect 63, 289-97.

422

423 Noyce, J. O., Michels, H. and Keevil, C. W. (2006b) Use of copper cast alloys to control 424 Escherichia coli $\mathrm{O} 157$ cross-contamination during food processing. Appl Environ Microbiol $425 \quad 72,4239-44$.

426

Quigley, L., O’Sullivan, O., Stanton, C., Beresford, T., Ross, P., Fitzgerald, G. and Cotter, P. 428 (2013) The complex microbiota of raw milk. FEMS Microbiol Rev 37, 664-698.

430 Raats, D., Offek, M., Minz, D. and Halpern, M. (2011) Molecular analysis of bacterial 431 communities in raw cow milk and the impact of refrigeration on its structure and dynamics. 432 Food Microbiol 28, 465-471.

434 Rademaker, J., Vissers, M., and te Giffel, M. (2007) Effective Heat Inactivation of 435 Mycobacterium avium subsp. paratuberculosis in Raw Milk Contaminated with Naturally 436 Infected Feces. Appl Environ Microbiol 73, 4185-4190.

438 Salgado, M., Verdugo, C., Heuer, C., Castillo, P. and Zamorano, P. (2014) A novel low cost 439 method for Mycobacterium avium subsp. paratuberculosis DNA extraction from an 440 automated broth culture system for a real time PCR confirmation. J Vet Sci 15, 233-239.

442 Skovgaard, N. (2007) New trends in emerging pathogens. Int J Food Microbiol $443 \mathbf{1 2 0}, 217-224$. 
444 Stabel, J. R. and Lambertz, A. (2004) Efficacy of Pasteurization Conditions for the

445 Inactivation of Mycobacterium avium subsp. paratuberculosis in Milk. J Food Prot 67, $446 \quad 2719-2726$.

448 Steuer, P., Avilez, C., Tejeda, C., González, N., Ramírez-Revecco, A., Ulloa, F., Mella, A., 449 Grant, I. R., Collins, M. T. and Salgado, M. (2018) In vitro inactivation of Mycobacterium 450 avium subsp. paratuberculosis (MAP) by use of copper ions. BMC Microbiol 18:172.

Steuer, P., Collado, B., Avilez, C., Tejeda, C., Soto, J.P. and Salgado, M. (2019). Is the transmission of Mycobacterium avium subspecies paratuberculosis (MAP) infection through milk intended to feed calves an overlooked item in paratuberculosis control programs? Trop Anim Health Prod 52, 89-94.

456

Development of a rapid phage-based method for the detection of viable Mycobacterium avium subsp. paratuberculosis in blood within 48 h. J Microbiol Meth 94, 175-179.

460

461 Velásquez-Ordoñez, V., Valladares-Carranza, B., Tenorio-Berroto, E., Talavera-Rojas, M., 462 Varela-Guerrero, J.A., Acosta-Dibarrat, J., Puigvert, F., Grille, L., González R., A. and Pareja, L. 463 (2019) Microbial Contamination in Milk Quality and Health Risk of the Consumers of Raw Milk 464 and Dairy Products. In Nutrition in Health and Disease. Our Challenges Now and Forthcoming 465 Time ed. Mzsik, G. IntechOpen. DOI: http://dx.doi.org/10.5772/intechopen.86182. 
467 Verdier-Metz, I., Gagne, G., Bornes, S., Monsallier, F., Veisseire, P., Delbes-Paus, C. and 468 Montel, M.C. (2012) Cow teat skin, a potential source of diverse microbial populations for 469 cheese production. Appl Environ Microbiol 78, 326-333.

470

471 Versoza, M., Jung, W., Barabad, M. L., Ko, S., Kim, M. and Park, D. (2019) Reduction of 472 Escherichia coli Using Metal Plates with the Influenced of Applied Low Current and Physical 473 Barrier of Filter Layers. Int J Environ Res Public Health 16, 3887.

474

475 Warnes, S. L., Green, S. M., Michels, H. T. and Keevil, C. W. (2010) Biocidal efficacy of 476 copper alloys against pathogenic enterococci involves degradation of genomic and plasmid 477 DNAs. Appl Environ Microbiol 76, 5390-5401.

478

Whan, L. B., Grant, I. R., Ball, H. J., Scott, R. and Rowe, M. T. (2001) Bactericidal effect of chlorine on Mycobacterium paratuberculosis in drinking water. Lett Appl Microbiol 33, 227231.

482

Wilks, S. A, Michels, H. and Keevil, C. W. (2005) Survival of Escherichia coli O157 on a range of metal surfaces. Int J Food Microbiol 105, 445-54.

485

486

487

488

489

490 
491 Table 1 Mean of triplicates values for MAP load, copper concentration, $\mathrm{pH}$, electrical

492 conductivity, and oxygen concentration estimated in MAP naturally contaminated milk after

493 the application of two strategies of copper ions treatment for exposure times ranging from $0-5$

$494 \min$.

\begin{tabular}{|c|c|c|c|c|c|c|c|c|c|c|}
\hline \multirow{3}{*}{$\begin{array}{c}\text { Cu exposure } \\
\text { time (min) }\end{array}$} & \multicolumn{2}{|c|}{ MAP load } & \multicolumn{2}{|c|}{$\mathrm{Cu}[$ ] } & \multicolumn{2}{|c|}{$\mathrm{pH}$} & \multicolumn{2}{|c|}{$\mathrm{EC}$} & \multicolumn{2}{|c|}{$\mathrm{O}_{2}$ concentration } \\
\hline & Complete & $\mathrm{Cu} \mathrm{TT}$ & No & Complete & No & Complet & No & Complete & $\mathrm{No}$ & Complete \\
\hline & $\mathrm{Cu} \mathrm{TT}{ }^{\mathrm{o}}$ & w/o E & $\mathrm{TT}$ & $\mathrm{Cu}$ TT & $\mathrm{TT}$ & $\mathrm{Cu} \mathrm{TT}$ & TT & $\mathrm{Cu}$ TT & $\mathrm{TT}$ & $\mathrm{Cu}$ TT \\
\hline 0 & $4.1 \times 10^{4}$ & $4.2 \times 10^{4}$ & 0.60 & 0.69 & 7.5 & 7.5 & 4.6 & 4.6 & 4.6 & 4.6 \\
\hline 1 & $2.2 \times 10^{4}$ & $3.8 \times 10^{4}$ & 0.61 & 1.9 & 7.5 & 7.7 & 4.5 & 4.6 & 4.6 & 4 \\
\hline 2 & $1.0 \times 10^{4}$ & $3.2 \times 10^{4}$ & 0.60 & 3.5 & 7.5 & 7.8 & 4.6 & 4.6 & 4.5 & 3.4 \\
\hline 3 & $6.3 \times 10^{3}$ & $2.8 \times 10^{4}$ & 0.62 & 5.7 & 7.5 & 9.1 & 4.5 & 4.7 & 4.5 & 3.1 \\
\hline 4 & $1.8 \times 10^{3}$ & $2.1 \times 10^{4}$ & 0.60 & 9.38 & 7.5 & 10.8 & 4.6 & 4.9 & 4.5 & 3 \\
\hline 5 & $4.2 \times 10^{2}$ & $1.1 \times 10^{4}$ & 0.61 & 15.6 & 7.5 & 11.7 & 4.5 & 5.1 & 4.6 & 2.8 \\
\hline
\end{tabular}

495 MAP load:

expressed in bce $\mathrm{ml}^{-1}$ :

$496 \mathrm{Cu}[\mathrm{]}:$

copper concentration expressed in $\mathrm{mg}^{-1}$

497 EC:

electrical conductivity expressed in $\mathrm{mS} \mathrm{cm}^{-1}$

$498 \mathrm{O}_{2}$ :

oxygen concentration expressed in $\mathrm{mg}^{-1}$

499 Complete $\mathrm{Cu}$ TT: copper plates immersed in the milk samples and stimulated with a low voltage (24V) electrical current (3 Amperes) for $5 \mathrm{~min}$

$501 \mathrm{Cu}$ TT w/o E: copper plates immersed in the milk samples without the application of 
507 Table 2 Mean MAP load (expressed as bce $\mathrm{ml}^{-1}$ ) after treatment of naturally contaminated

508 milk (in triplicate) with different concentrations of copper sulphate $\left(\mathrm{CuSO}_{4}\right)$ for 1 and 7 days

509 of exposure.

\section{MAP load (bce ml-1)}

\begin{tabular}{|c|c|c|}
\hline \multicolumn{3}{|l|}{$\mathrm{CuSO}_{4}$} \\
\hline concentration & Day 1 & Day 7 \\
\hline $6.5 \mu \mathrm{M}$ & $4.2 \times 10^{4}$ & $4.3 \times 10^{4}$ \\
\hline $12.5 \mu \mathrm{M}$ & $4.1 \times 10^{4}$ & $2.2 \times 10^{4}$ \\
\hline $25 \mu \mathrm{M}$ & $3.1 \times 10^{4}$ & $2.0 \times 10^{4}$ \\
\hline $50 \mu \mathrm{M}$ & $2.5 \times 10^{4}$ & $3.8 \times 10^{4}$ \\
\hline $100 \mu \mathrm{M}$ & $2.0 \times 10^{4}$ & $5.2 \times 10^{4}$ \\
\hline $250 \mu \mathrm{M}$ & $3.3 \times 10^{4}$ & $4.1 \times 10^{4}$ \\
\hline $500 \mu \mathrm{M}$ & $4.5 \times 10^{4}$ & $6.2 \times 10^{4}$ \\
\hline $750 \mu \mathrm{M}$ & $3.2 \times 10^{4}$ & $8.1 \times 10^{4}$ \\
\hline $1.0 \mathrm{mM}$ & $8.9 \times 10^{3}$ & $5.1 \times 10^{4}$ \\
\hline $1.5 \mathrm{mM}$ & $9.2 \times 10^{3}$ & $5.3 \times 10^{4}$ \\
\hline $2.0 \mathrm{mM}$ & $7.6 \times 10^{3}$ & $6.2 \times 10^{4}$ \\
\hline $2.5 \mathrm{mM}$ & $1.7 \times 10^{4}$ & $4.8 \times 10^{4}$ \\
\hline $3.0 \mathrm{mM}$ & $1.5 \times 10^{4}$ & $4 . \times 10^{4}$ \\
\hline $3.5 \mathrm{mM}$ & $2.3 \times 10^{4}$ & $4.2 \times 10^{4}$ \\
\hline $4.0 \mathrm{mM}$ & $9.5 \times 10^{3}$ & $3.1 \times 10^{4}$ \\
\hline $4.5 \mathrm{mM}$ & $8.5 \times 10^{3}$ & $1.2 \times 10^{4}$ \\
\hline $5.0 \mathrm{mM}$ & $1.0 \times 10^{4}$ & $3.3 \times 10^{4}$ \\
\hline $10.0 \mathrm{mM}$ & $1.5 \times 10^{4}$ & $6.2 \times 10^{4}$ \\
\hline $50.0 \mathrm{mM}$ & $2.2 \times 10^{4}$ & $3.7 \times 10^{4}$ \\
\hline $100.0 \mathrm{mM}$ & $1.1 \times 10^{4}$ & $2.4 \times 10^{4}$ \\
\hline
\end{tabular}


510 Table 3 MAP counts (mean PFU per $50 \mathrm{ml}$ of the duplicates) in raw milk samples determined

511 by PMS-phage assay before and after treatment with copper ions at $24 \mathrm{~V}$ for $5 \mathrm{~min}$

\begin{tabular}{|c|c|c|c|}
\hline Milk sampling & Untreated milk samples & $\begin{array}{c}\text { Copper-treated } \\
\text { milk samples }\end{array}$ & $\begin{array}{c}\text { Log } 10 \text { reduction } \\
\text { observed }\end{array}$ \\
\hline I & $1.0 \times 10^{5}$ & $1.5 \times 10^{4}$ & 0.82 \\
\hline II & $3.3 \times 10^{4}$ & $4.0 \times 10^{2}$ & 1.91 \\
\hline III & $1.8 \times 10^{1}$ & 3.0 & 0.78 \\
\hline IV & $1.1 \times 10^{2}$ & $<1.0$ & 2.04 \\
\hline $\mathbf{V}$ & $3.3 \times 10^{2}$ & $<1.0$ & 2.51 \\
\hline VI & $5.0 \times 10^{4}$ & $4.0 \times 10^{2}$ & 2.09 \\
\hline VII & $2.0 \times 10^{3}$ & $1.5 \times 10^{1}$ & 2.12 \\
\hline VIII & $4.0 \times 10^{4}$ & $3.8 \times 10^{2}$ & 2.02 \\
\hline Median value (range) & $1.75 \times 10^{4}\left(1.8 \times 10^{1}-1.0 \times 10^{5}\right)$ & $1.97 \times 10^{2}$ & 1.79 \\
\hline
\end{tabular}

512 *Only experimental results validated with proper positive and negative controls have been

513 included in this table.

514

515 
516 Table 4 MAP load estimations (mean MAP bce $\mathrm{ml}^{-1}$ of the duplicates) determined by qPCR

517 for untreated and copper-treated (24V for $5 \mathrm{~min}$ ) raw milk samples

\begin{tabular}{|c|c|c|c|}
\hline Milk Sampling & Untreated milk samples & $\begin{array}{c}\text { Copper-treated } \\
\text { milk samples }\end{array}$ & $\begin{array}{c}\text { Log10 reduction } \\
\text { observed }\end{array}$ \\
\hline I & $3.83 \times 10^{3}$ & ND & 3.58 \\
\hline II & $3.56 \times 10^{3}$ & ND & 3.55 \\
\hline III & $5.24 \times 10^{3}$ & ND & 3.72 \\
\hline IV & $4.49 \times 10^{3}$ & $2.3 \times 10^{1}$ & 2.29 \\
\hline V & $1.16 \times 10^{3}$ & ND & 3.06 \\
\hline VI & $4.75 \times 10^{2}$ & ND & 2.67 \\
\hline VII & $3.38 \times 10^{4}$ & ND & 4.52 \\
\hline VIII & $6.23 \times 10^{2}$ & ND & 2.79 \\
\hline Median value (range) & $3.69 \times 10^{3}\left(4.75 \times 10^{2}-3.38 \times 10^{4}\right)$ & & 3.27 \\
\hline
\end{tabular}

518 ND: no MAP DNA detected.

519

520

521

522

523

524

525

526

527

528

529 
530 Table 5 Calculated primer pair efficiencies used in the taxon-specific qPCR assay

\begin{tabular}{llcc}
\hline Target taxon & Primer pair & Slope of the line & Efficiency (\%) \\
\hline Universal & $907 \mathrm{~F}+106 \mathrm{R}$ & -3.42 & 96.06 \\
Actinobacteria & Act920F3+act1200R & -3.5 & 93.1 \\
$\gamma$-Proteobacteria & $1080 \mu \mathrm{F}+\mu 1202 \mathrm{R}$ & -3.3 & 100.9 \\
Bacteroidetes & $798 \mathrm{cfbF}+\mathrm{cbf} 967 \mathrm{R}$ & -3.47 & 94.1 \\
Firmicutes & $928 \mathrm{firmF}+1040 \mathrm{firmR}$ & -3.63 & 88.5 \\
\hline
\end{tabular}

531

532 


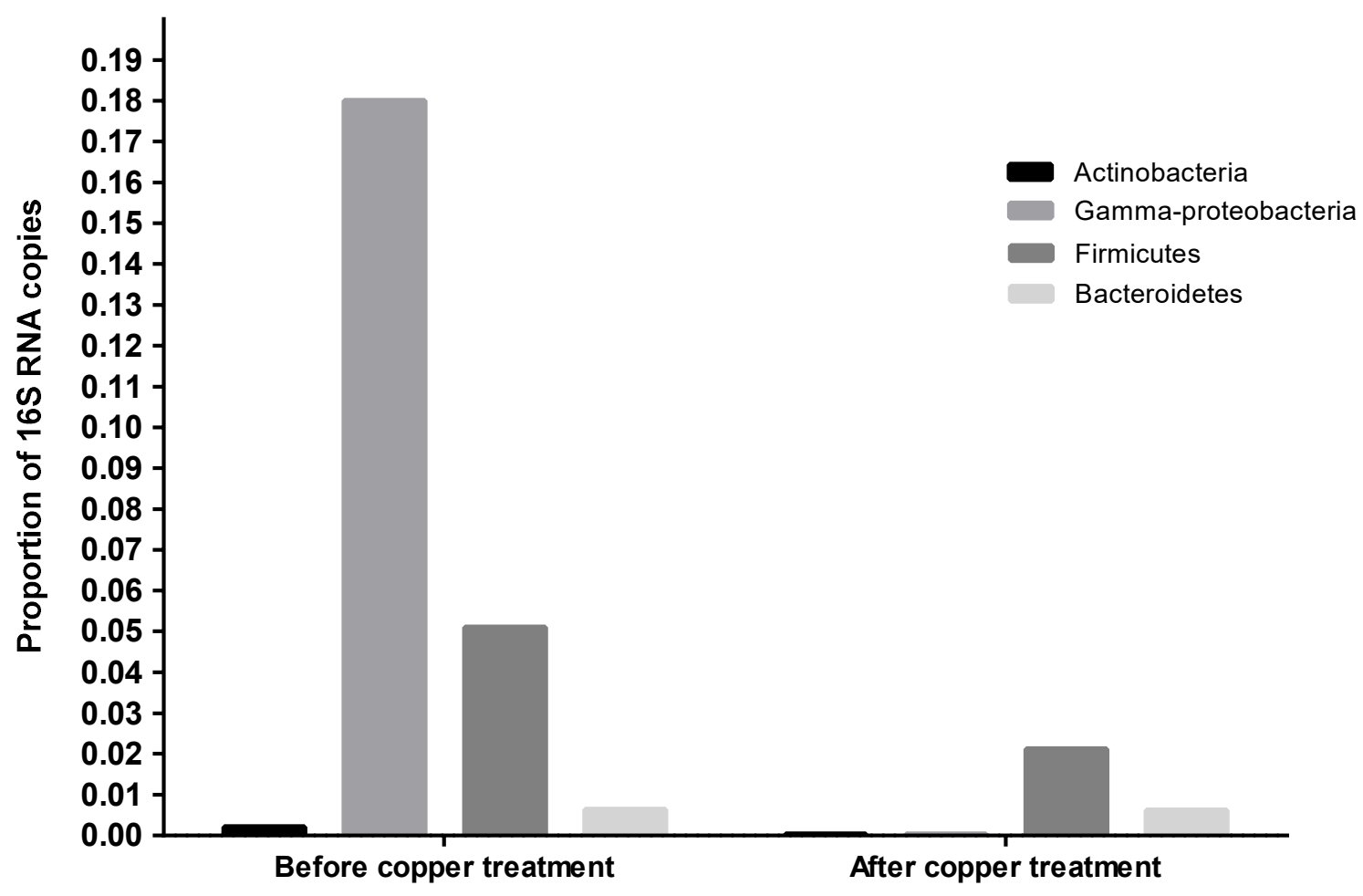

535 Figure 1. Relative quantification of $16 \mathrm{~S}$ rRNA copies belonging to each phylum present in 536 raw milk samples before and after treatment with copper ions. 

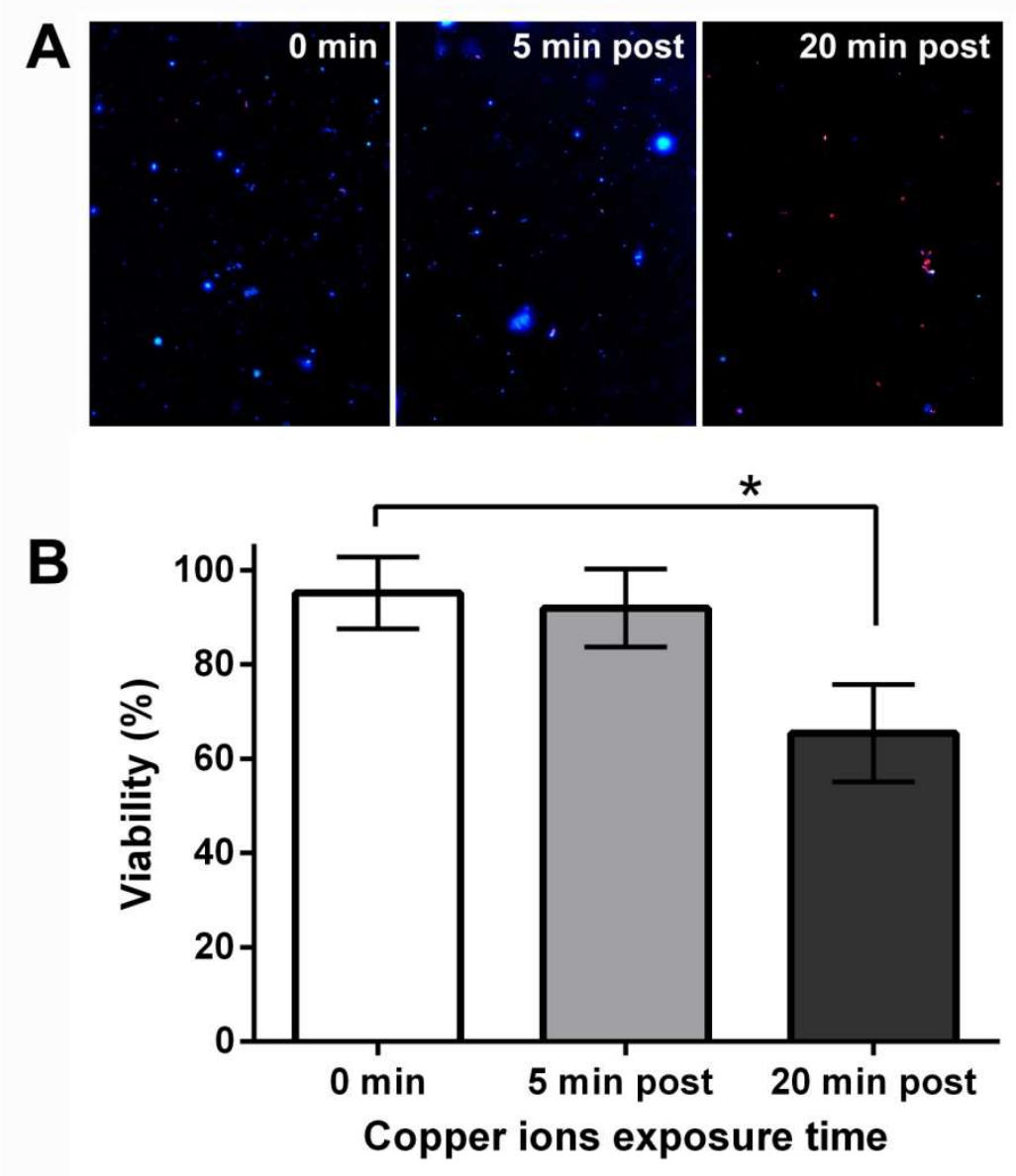

550 Figure 2. Plasma membrane integrity or viability (\%) analysis by Hoechst 33342/Propidium

551 iodide stain. A: Representative field captures for plasma membrane integrity analysis by,

552 blue green or red fluorescents marks, corresponding to bacterial cells recognized as live or

553 dead, respectively, after different copper ions exposure times (0, 5 and $20 \mathrm{~min}) \mathrm{B}$ :

554 Quantification of the cell viability loss after the same copper ions treatments. A minimum of

555100 cells were counted for each sample. Each bar represents the mean \pm SD of a total of three

556 independent experiments. Significant differences between exposure times are shown one-way

557 ANOVA Kruskal-Wallis / Dunn tests $(*: \mathrm{p}<0.05)$. 